\title{
Ekonomi Indonesia 1950-an dan Penguasaan Negara terhadap Perusahaan Kereta Api Pasca-KMB 1949
}

\author{
Waskito Widi Wardodjo \\ Program Studi Ilmu Sejarah, Fakultas Ilmu Budaya, Universitas Negeri Surakarta \\ Program Studi Doktor Sejarah, Fakultas Ilmu Budaya, Universitas Diponegoro
}

Alamat korespondensi: widiwardoyo@gmail.com

Diterima/ Received: 10 Desember 2018

Disetujui / Accepted: 28 Desember 2018

\begin{abstract}
The prominent feature of the Indonesian economy in the 1950s was the dualistic nature that shows a division between the modern and subsistence traditional agriculture sector. The modern economy sector was the major industry controlled by Dutch companies. The focus of this research is to briefly describe the government's economic program as a new sovereign state such as the Benteng program. There are some major research problems which should be analyzed; (1) The Indonesian government's economic nationalization strategy to change the economic structure that is still controlled by the colonial; (2) The state's effort to nationalize Dutch companies, especially railway companies. There were eleven railway companies that were affected by the nationalization policy. The results show that both state-owned and private-owned railway companies were affected by nationalization eventually accepted the policy as a consequence of a sovereign state with certain compensation. It happened after going through quite a dynamic diplomacy.
\end{abstract}

Keywords: Nationalization; Railway Companies; Economic Dualism.

\begin{abstract}
Abstrak
Ciri ekonomi Indonesia yang menonjol pada 1950-an bersifat dualistik yang menampilkan perpecahan cukup tajam antara sektor ekonomi modern dan pertanian tradisional yang subsisten. Sektor modern yakni industri mayoritas dikuasai oleh perusahaan Belanda. Fokus penelitian ini untuk menggambarkan secara singkat program ekonomi pemerintah sebagai negara yang baru berdaulat seperti program Benteng. Bagaimana strategi nasionalisasi ekonomi pemerintah Indonesia guna mengubah struktur ekonomi yang masih dikuasai kolonial? Bagaimana upaya negara dalam melakukan nasionalisasi terhadap perusahaan Belanda, khususnya perusahaan kereta api? Terdapat sebelas perusahaan kereta api yang terkena kebijakan nasionalisasi. Hasil penelitian menunjukkan bahwa perusahaan kereta api milik negara dan swasta yang terkena nasionalisasi pada akhirnya menerima kebijakan tersebut sebagai konsekuensi sebuah negara berdaulat dengan kompensasi tertentu, setelah melalui dinamika diplomasi yang cukup alot.
\end{abstract}

Kata Kunci: Nasionalisasi; Perusahaan Kereta Api; Dualisme Ekonomi.

\section{Pendahuluan}

Kolonialisme turut menumbuhkan kesadaran bahwa tanah yang dieksploitasi oleh penjajah dipergunakan untuk kesejahteraan kolonial (penjajah) dan bukan untuk tanah yang dijajah. Tumbuhnya kesadaran tersebut merupakan bagian dari rasa nasionalisme berbangsa. Saat nasionalisme menemukan bentuknya dalam negara bangsa, republik pascaproklamasi kemerdekaan 1945 ternyata tidak mudah 
melepaskan diri dari cengkeraman kepentingan ekonomi Barat. Kedaulatan negara masih terancam, meskipun perlawanan heroik dengan bambu runcing mampu mengusir penjajah, tetapi belum cukup mencapai cita-cita masyarakat yang adil dan makmur seperti yang tertuang dalam Pembukaan UUD 1945. Bahkan, kedaulatan negara baru diakui oleh Belanda pada 1949 melalui Konferensi Meja Bundar (KMB) dengan berbagai keputusan yang merugikan republik.

Bentuk negara hasil kesepakatan KMB juga bukan republik, melainkan Republik Indonesia Serikat (RIS) berdasar UUD Sementara dan bukan UUD 1945. Dibentuklah persatuan Indonesia-Belanda dengan Ratu Belanda sebagai ketua persatuan. Ironisnya, pemerintah RIS juga mesti melunasi utang Hindia Belanda kepada negara induk Belanda sebesar 4,5 miliar gulden (Kanumoyoso, 2001, pp. 4849). Dalam kesepakatan tersebut, semua aset asing dikembalikan, negara boleh mengambilnya dengan kompensasi tertentu. Berarti secara ekonomi, pada saat itu republik telah terpenjara. Dalam bidang politik, klausul KMB yang menyatakan akan adanya pengembalian Irian Barat, ternyata tidak dilakukan oleh Belanda. Padahal, pascakemerdekaan telah dilakukan dua peralihan aset ekonomi yaitu peralihan kelembagaan dari pemerintah Belanda kepada pemerintah RI dan nasionalisasi. Pertama lebih ditujukan terhadap aset-aset milik pemerintah, sedangkan yang kedua untuk aset-aset lembaga nonpemerintah baik milik swasta asing maupun badan usaha milik pemerintah Hindia Belanda. Termasuk di dalamnya adalah nasionalisasi terhadap 12 perusahaan kereta api di Indonesia. Proses nasionalisasi ini dimulai saat usainya Konferensi Meja Bundar pada 1949 yang menghasilkan salah satu kesepakatan adanya nasionalisasi terhadap perusahaan milik negara, termasuk perusahaan kereta api negara Belanda (Staatspoor), di samping kesepakatan lain seperti penyerahan Irian Barat setahun kemudian serta diizinkannya orang-orang Belanda untuk berbisnis kembali di Indonesia. Kemudian mencapai puncaknya pada tahun 1958 bersamaan dengan munculnya UU No. 86 Tahun 1958 tentang Nasionalisasi Perusahaan Milik Belanda. Kebijakan ini menjadi cikal bakal perusahaan negara yang kini dikenal sebagai Badan Usaha Milik Negara. Nantinya berbagai perusahaan negara ini berperan penting dalam perkembangan ekonomi politik rezim Orde Baru. Bagaimana strategi negara dalam mengubah tatanan struktur ekonomi yang masih dikuasai kolonial Belanda? Bagaimana pula nasionalisasi terhadap perusahaan kereta api pasca-KMB 1949?

\section{Metode}

Metode penelitian ini mengacu kepada metode penelitian sejarah seperti yang diungkapkan oleh Garraghan (1940). Metode ini memiliki empat hal; heuristik, kritik sumber, interpretasi data, dan historiografi. Pada tahap heuristik, ditemukan beberapa sumber tertulis di beberapa lembaga. Arsip Nasionalisasi Perusahaan Belanda yang disimpan di Arsip Nasional Jakarta yang berupa arsip NederlandschIndische Spoorweg Maatschappij (NISM) dan Serdang Cultuur Maatschappij (SCM) serta sumber sejarah sezaman yang tersimpan di Arsip Nasional Belanda di Den Haag. Kedua, jenis arsip tersebut banyak memuat tentang nasionalisasi kereta api termasuk perhitungan ganti rugi, termasuk notulensi rapat mengenai pembahasan itu. Selain itu, juga menelusuri Majalah Kereta Api yang diterbitkan oleh Serikat Buruh Kereta Api serta koran-koran sezaman yang tersimpan di Perpustakaan Nasional, Perpustakaan CSIS, dan Perpustakaan LIPI di Jakarta. Sementara itu, diperoleh juga data statistik mengenai jumlah penduduk. Melalui berbagai sumber di atas kemudian dilakukan kritik intern dan ekstern guna memeroleh fakta sejarah yang akan diinterpretasikan dalam upaya membangun fakta. Fakta-fakta ini kemudian dituangkan dalam langkah akhir yaitu historiografi. 


\section{Nasionalisme Ekonomi dan Strategi Menyiasati Kondisi}

Para founding fathers bangsa menyadari bahwa sosialisme merupakan negasi dari kapitalisme sehingga menggunakan ideologi tersebut termasuk dalam perumusan visi ekonomi Indonesia yang berbunyi: perekonomian disusun sebagai usaha bersama berdasar asas kekeluargaan. Bumi, air, kekayaan alam di dalamnya, dan cabang-cabang produksi yang menguasai hajat hidup orang banyak dikuasai oleh negara untuk kemakmuran rakyat yang sebesar-besarnya. Namun demikian, bukan berarti menjadi etatisme komunisme apabila penguasaaan aset dan kekayaan sumber daya alam dikelola oleh negara. Tampak bahwa spirit sosialisme religius menjiwai UUD 1945 walaupun tidak eksplisit. Pada masa Soekarno spirit sosialisme serta berdikari tanpa bantuan utang luar negeri cukup kental, dan ketergantungan terhadap bantuan asing atau utang lambat laun akan menggerus kedaulatan ekonomi nasional. Sosialisme Indonesia memiliki ciri khas tersendiri, sehingga tidak bisa disamakan dengan Uni Soviet pada saat itu. Faktanya, masih adanya kepemilikan pribadi dalam penguasaan aset-aset produksi.

Sosialisme atau komunisme dipahami sebagai suatu sistem sosial yang mendudukkan kepemilikan aset produksi di bawah kuasa penuh pemerintah, sehingga aset pribadi tidak diakui eksistensinya. Pemerintah adalah aktor tunggal mulai dari merencanakan, memproduksi, distribusi, hingga evaluasi sehingga tidak ada sistem mekanisme pasar. Sebaliknya, kapitalisme sebagai suatu sistem ekonomi mengakui hak individu dalam penguasaan aset produksi. Terdapat sebuah karakter kebebasan dalam mencapai kesejahteraan material oleh masing-masing individu. Oleh karena itu, iklim kompetisi begitu ketat dalam wilayah ini sehingga peran pemerintah tidak begitu kelihatan dan sebatas regulator yang memastikan adanya level playing ground yang sama.

Dalam perkembangan kedua ideologi dunia ini, pertentangan untuk mencapai kesejahteraan masyarakat terus terjadi. Depresi ekonomi dunia tahun 1930 telah menurunkan kepercayaan masyarakat terhadap sosialisme. Guna memaknai sosialisme Indonesia pada masa Orde Lama, Mackie (1971, p. 44) berpendapat dua hal; Pertama, istilah 'Indonesianisasi" tidak hanya replika modal asing, terutama yang dimiliki Belanda atau keturunan Cina; Kedua, ditekankan pada bentuk organisasi ekonomi yang berlandaskan prinsip gotong royong dan bukan individualis atau profit laba. Dalam konteks ini, koperasi adalah organisasi yang menjadi harapan mengingat cita-cita sosial masyarakat Indonesia.

Karena itulah mayoritas kelembagaan ekonomi negara pascakemerdekaan merupakan kelanjutan dari kelembagaan ekonomi yang pernah diterapkan oleh pemerintah kolonial sebelum kemerdekaan. Namun demikian, adanya kolonialisme dan gerakan nasionalis serta peran militer yang koersif memengaruhi bentuk kelembagaan ekonomi negara. Sebagaimana Todaro dan Smith (2012, p. 70) menyatakan bahwa kolonialisme berdampak pada pengaturan hak milik pribadi, pajak personal, dan ketentuan bahwa pajak harus dibayar dalam bentuk uang dan bukan barang (Rahmat dan Yustika, 2017, p.61). Sekali lembaga ini terbentuk, akan sulit sekali menggantikan lembaga warisan kolonial ini, kecuali muncul dua hal, yaitu gerakan nasional antikolonial dan militer.

Pengaruh gerakan nasional rupanya lebih dominan daripada militer yang muncul belakangan. Ini tampak dari institusi ekonomi yang dipengaruhi oleh gagasan para tokoh pergerakan yang tumbuh subur bercorak ideologi sosial demokrat sejak awal abad XX. Adanya nasionalisasi perusahaan asing menandaskan terjadinya perubahan kepemilikan sejumlah perusahaan yang sebelumnya dimiliki oleh pemerintah kolonial menjadi milik negara, serta yang sebelumnya milik swasta kolonial menjadi milik republik, yang nantinya bermetamorfosa menjadi perusahaan milik negara dengan pengelolaan model swasta. Fakta lain yang menegaskan perubahan kepemilikan adalah munculnya UU Nomor 5 Tahun 1960 mengenai 
Reformasi Agraria. Munculnya undang-undang ini telah menjadi dasar hukum bagi pelaksanaan land reform di masa orde lama yang mengubah konsep kepemilikan tanah di tangan pemerintah pada masa kolonial, menjadi kepemilikan di tangan pribadi (Pelzer dalam Glassburner, 1971, p. 138).

Memudarnya sistem ekonomi kapitalis juga turut mendorong menguatnya sentralisme ekonomi, terutama sejak peristiwa depresi besar pada 1930 yang kemudian semakin meruntuhkan keyakinan terhadap ekonomi pasar. Sebaliknya zeitgeist (semangat zaman) sosialisme ekonomi mengalami kebangkitan setelah keberhasilan revolusi Bolshevik mendirikan negara sosialis pertama di dunia yaitu Uni Sovyet pada 1922. Inilah salah satu pemantik yang melatarbelakangi gagasan pemikiran para tokoh pergerakan nasional, sehingga berpengaruh terhadap paradigma berpikir alternatif di luar kapitalisme.

Gagasan pemikiran para tokoh pergerakan turut memengaruhi orientasi pembangunan ekonomi Indonesia sejak proklamasi kemerdekaan yang akan mengubah tatanan struktur kolonial menjadi nasional. Walaupun ternyata mengalami hambatan setelah kesepakatan Konferensi Meja Bundar (KMB) pada 23 Agustus-2 Nopember 1949 yang mewajibkan pemerintah Indonesia membayar beban utang pemerintah kolonial Belanda sebesar 4,3 miliar gulden (Ricklef, 2008, pp. 497-488). Dengan kesepakatan ini tampak bahwa kepentingan kolonial masih mendominasi, terutama perusahaan-perusahaan milik Belanda yang dikendalikan langsung oleh orang-orang Belanda. Hingga 1952 aktivitas perdagangan internasional masih dikuasai oleh perusahaan milik Belanda. Tak kurang dari 50\% impor barang konsumsi dilakukan oleh delapan perusahaan milik Belanda. Termasuk sektor perbankan yang dikuasai oleh tujuh bank asing yang mana tiga di antaranya dimiliki oleh Belanda (Glassburner, 1971, pp. 78-80). Bank Indonesia pada 1952-1953 melaporkan hanya 19\% dari modal di sektor nonpertanian dimiliki kaum pribumi, selebihnya milik asing. Laporan tersebut juga menyatakan bahwa total transfer profit yang dikirim ke Belanda pada 1953 sebesar Rp 499 juta atau 70\%; transfer sosial (tabungan pribadi dan dana pensiun) sebesar Rp 464 juta (83\%) (Thee Kian Wie, 2011, p. 59). Realitas demikian menjadi sulit diterima oleh para tokoh gerakan nasional. Penguasaan aset memunculkan wacana Indonesianisasi serta kedaulatan pribumi. Apalah arti kemerdekaan apabila sebagian sumber daya ekonomi masih dikuasai pihak asing. Artinya, walapun Indonesia sudah merdeka secara politik, namun secara ekonomi masih tetap terjajah.

Sebenarnya kebijakan nasionalisasi sudah mulai dilakukan secara gradual. Dimulai pada masa Perdana Menteri Moh. Hatta yang melakukan nasionalisasi jalur kereta api pada 1949-1950, dilanjutkan nasionalisasi Java bank yang berganti nama menjadi Bank Indonesia (BI) pada 1951 di bawah koordinasi Menteri Sukiman (19511952). Baru pada 22 Mei 1956, Pemerintah Indonesia membatalkan secara sepihak hasil KMB dengan mengeluarkan UU Nomor 13 Tahun 1956.

Jadi antara nasionalisme dan ekonomi berpadu menjadi satu dalam bingkai politik kebijakan menuju kesejahteraan masyarakat. Salah satu syarat menuju cita ideal kesejahteraan, manakala negara memiliki kedaulatan ekonomi yang kuat di depan bangsa asing. Pemahaman tentang nasionalisme ekonomi juga diartikan sebagai upaya mengisolasi perekonomian dari pengaruh asing. Hal ini wajar bagi negara yang baru saja terbebas dari kolonialisme, ingin segera mengubah perekonomian kolonial menjadi perekonomian nasional. Salah satu caranya ialah memperbesar peran pribumi dalam kepemilikan dan penguasaan aset produktif di luar bidang pertanian yang cenderung subsisten. Meminjam istilah Yahya Muhaimin, pada periode pembenahan 1950-an, dilakukan berbagai upaya untuk meningkatkan peran pribumi dalam bidang ekonomi.

Salah satu gerakan politik pribumisasi ekonomi adalah gerakan yang dilakukan oleh Assat, yang sempat menjabat Presiden RI pada periode 1949-1950. 
Gerakan rasialis ini, tulis Ian Chalmers, menegaskan perlunya menarik garis tegas pemisah antara warga negara asli dan warga keturunan Cina, sekaligus mendesak diberlakukannya UU yang menetapkan bahwa semua perusahaan nasional harus dikelola dan didominasi kepemilikannya oleh kaum pribumi. Namun gerakan ini ternyata gagal karena tidak ada dukungan sama sekali dari partai politik (Chalmers, 1996, p. 109).

Terdapat dua faktor yang berperan dalam nasionalisasi perusahaan milik Belanda, yaitu politik dan ekonomi. Pada aspek politik, Belanda tidak menjalankan hasil KMB yang telah menyetujui pembahasan masalah Irian Barat setahun kemudian (1950). Pada Nopember 1957, pemerintah Indonesia mengajukan resolusi melalui Sidang Umum Perserikatan Bangsa-Bangsa (PBB), namun tidak memperoleh dukungan karena beberapa negara abstain.

Klimaks hubungan Indonesia-Belanda pada waktu kabinet Burhanudin Harahap membatalkan hasil Konferensi Meja Bundar (KMB) secara sepihak pada 1956. Pemerintah Indonesia perlu mengambil sikap tegas dan bertekad menyelesaikan sengketa Irian Barat. Sementara pemerintah Belanda tidak bersedia membahas Irian Barat karena menganggap pemerintah Indonesia tidak mampu menyediakan sarana dan mendidik masyarakat Irian Barat dengan baik. Faktor ekonomi, melihat secara faktual bahwa walaupun Indonesia sudah merdeka, perekonomian masih dikuasai oleh perusahaan-perusahaan swasta milik Belanda. Kondisi perekonomian Indonesia pada awal 1950 masih buruk. Betapa tidak, perang kemerdekaan selama empat tahun membuat kas negara kosong, mengeluarkan banyak uang, padahal negara belum memiliki pendapatan. Ditambah dengan blokade Belanda terhadap kegiatan ekspor perusahaan-perusahaan besar yang ada di Indonesia. Dampaknya, kegiatan ekspor barang-barang dari Indonesia tersendat dan bahkan berhenti selama kurun waktu 1945 hingga awal 1950-an, ditambah dengan hasil kesepakatan KMB yang mencicil 4,3 juta gulden, yang kemudian telah dilakukan pembayaran hingga lima tahun hingga mencapai sekitar 4 juta gulden, sebelum pemerintah Indonesia membatalkan hasil KMB (Kanumoyoso, 2001, p. 49).

Ekonomi Indonesia merosot pada 1950-an sehingga membuat para tokoh Indonesia memikirkan konsep pembangunan ekonomi nasional. Nasionalisme ekonomi diartikan sebagai aspirasi suatu bangsa untuk memiliki atau setidaknya menguasai aset-aset yang dimiliki atau dikuasai oleh bangsa lain dan menjalankan fungsi ekonomi yang dijalankan oleh bangsa lain. Inilah yang disebut sebagai nasionalisasi ekonomi. Sebenarnya gagasan untuk membangun ekonomi nasional telah muncul sejak awal kemerdekaan. Dalam Konferensi ekonomi pada 3 Februari 1946, Mohammad Hatta menegaskan bahwa apabila masih ada kerjasama ekonomi antara Indonesia dengan Belanda, akan menjadikan Indonesia merasa terbebani dan tidak dapat mendidik Indonesia untuk tumbuh menjadi negara yang berdaulat secara ekonomi. Hal tersebut menunjukkan bahwa ada keinginan untuk bisa terlepas dari perekonomian yang telah ditanamkan oleh Belanda.

Perekonomian yang telah berlangsung di Indonesia, merupakan warisan Belanda termasuk beberapa industri seperti pertambangan, transportasi, perkebunan, perkapalan, perbankan, hingga hiburan. Akan tetapi, eksistensi perusahaan-perusahaan Belanda ini dikhawatirkan akan menghambat laju pertumbuhan ekonomi nasional. Kekhawatiran ini muncul karena perusahaanperusahaan tersebut masih dikuasai oleh pihak swasta Belanda.

Kebijakan perekonomian pemerintah Orde Lama pada awal 1950-an, sebenarnya sudah bercorak nasionalistik. Termasuk program yang disebut Rencana Urgensi Perekonomian (RUP) sebagai usaha mengubah struktur perekonomian kolonial menjadi perekonomian nasional. RUP yang digagas oleh Soemitro Djojohadikusumo tersebut diwujudkan dalam bentuk Program Benteng. Program yang berusaha memberi kesempatan lebih bagi pengusaha pribumi agar mampu 
bersaing dengan pedagang asing dan Cina. Caranya ialah, memberi kesempatan kepada pengusaha pribumi melalui bantuan kredit. Upaya ini diharapkan menciptakan kelas pengusaha pribumi yang mampu meningkatkan produktivitas barang dan modal domestik.

Terdapat dua persoalan yang dihadapi dalam mengimplementasikan konsep nasionalisasi. Pertama, sedikitnya jumlah orang Indonesia yang terampil dan berpengalaman dalam melakukan perencanaan dan melaksanakan kebijaksanaan dalam mendorong perkembangan kelas pengusaha golongan pribumi. Kedua, perusahaan-perusahaan milik asing dan orang Cina mendominasi sektor-sektor ekonomi modern sementara orang Indonesia tidak memiliki ketrampilan berbisnis dan modal (Muhaimin, 1991, p. 5).

Dengan keterbatasan pengalaman, modal, dan tenaga kerja itulah yang berpengaruh terhadap minimnya kesuksesan munculnya pengusaha pribumi guna bersaing dengan pemodal Belanda maupun Cina. Kenyataan menunjukkan bahwa Program Benteng tidak sesuai seperti yang diharapkan dalam mengangkat pengusaha pribumi. Pemberian lisensi impor banyak yang disalahgunakan. Mereka yang menerima lisensi bukanlah pengusaha pribumi melainkan pengusaha Cina yang memiliki modal usaha yang kuat. Perusahaan yang lahir dari model ini dikenal sebagai perusahaan "Ali-Baba". Ali merepresentasi kelompok pengusaha pribumi, sedangkan Baba mewakili pengusaha warga keturunan Cina. Karena itulah konsep Ali Baba justru berkembang dalam perwujudan kolusi antara pengusaha Cina dan pengusaha pribumi. Upaya memanfaatkan kekuasaan negara untuk mengembangkan pengusaha pribumi gagal disebabkan oleh pergeseran lokus kekuasaan politik selama awal era 1950-an yang telah memecah komunitas bisnis sejalur dengan aliranaliran politik karena para importer beraliansi dengan partai-partai politik yang berlainan (Feith dan Castle, 1990). Termasuk tidak memadainya ketentuan pemberian kredit kepada para importir yang terdaftar, yang mengalami kesulitan pada 1953-1954. Akibatnya, proteksi negara sering diperluas guna menjangkau importir "aktentas", yaitu pialang yang berhasil memperoleh lisensi namun tidak memiliki dana sehingga mengandalkan kapitalis terampil, umumnya pada saat itu dimiliki pengusaha Cina yang kuat secara modal dan manajerial, tetapi secara politis tidak memperoleh lisensi. Dalam periode 1956-1957, sempat terjadi pembukaan Program Benteng untuk pengusaha Cina pada 1955, tetapi secara resmi program ini ditutup pada 1957.

Terbitlah UU No. 86 Tahun 1958 tentang Nasionalisasi PerusahaanPerusahaan Belanda. Setelah disahkan, muncul reaksi beragam baik dari internal maupun eksternal. Dari kalangan internal dalam negeri, para politisi menganggap bahwa terbitnya UU tersebut merupakan bagian dari manuver Soekarno guna memperbaiki perekonomian. Sementara secara eksternal, muncul protes dari kalangan pengusaha Belanda yang menganggap bahwa nasionalisasi yang dilakukan menyalahi peraturan hukum internasional. Namun demikian, tuntutan para pengusaha Belanda, termasuk perusahaan perkebunan maupun kereta api, ditolak oleh pengadilan Bremen Jerman pada 16 Juni 1959 (Achmad, 1963).

Bersamaan dengan penerapan UU Nasionalisasi Perusahaan Milik Belanda, kondisi politik tanah air semakin memanas. Muncul berbagai pemberontakan dari daerah di Sulawesi dan Sumatera seperti PRRI/ Permesta yang membuat Soekarno membuat Demokrasi Terpimpin. Di sini kelompok militer mulai muncul dalam pentas politik Indonesia pascakeberhasilannya menumpas berbagai pemberontakan di daerah tersebut. Militer pula yang diberi wewenang untuk mengambil alih berbagai perusahaan asing milik Belanda dengan melandaskan pada UU Nasionalisasi. Perusahaan bekas milik Belanda tersebut kemudian menjadi perusahaan milik negara yang dibagi-bagikan sebagai patronase militer dan elite 
birokrasi dan digabungkan dengan perusahaan serta korporasi lain milik negara (Muhaimin, 1990, p. 98).

Seperti diketahui, pascaproklamasi pemerintah telah membentuk berbagai perusahaan negara seperti Bank Negara Indonesia (BNI), Djawatan Angkutan Motor Indonesia (DAMRI), Garuda Indonesia Airline (GIA), Perusahaan Pelayaran Nasional (PELNI), serta beberapa industri milik negara. Beberapa perusahaan negara didirikan melalui nasionalisasi dengan skema membayar ganti rugi seperti Bank Indonesia yang sebelumnya adalah bank sentral De Javasche Bank. Sementara perkebunan dan pertanian dalam skala besar dimasukkan menjadi Perusahaan Perkebunan Negara (PPN) yang pada masa Orde Baru diorganisasi menjadi enam perusahaan negara. Adapun perusahaan kereta api swasta milik pengusaha Belanda yang dinasionalisasi ialah NISM, SCS, Serajoedal Stoomtram Maatschappij (SDS), Semarang-Joana Stoomtram Maatschappij (SJS), Malang Trem, Kediri Trem, Modjokerto trem, Pasuruan Trem, Probolinggo Trem, serta Madura Trem.

Proses nasionalisasi ini memberikan gambaran pentingnya peran militer terutama Angkatan Darat (AD). Juanda selaku Perdana Menteri saat itu menunjuk Kolonel Suprajogi menjadi Menteri Urusan Stabilisasi Ekonomi; Kolonel Baramuli menjadi Kepala Badan Pengurusan Perusahaan Daerah (Bappeda) yang berwenang mengawasi proses nasionalisasi terhadap perusahaan daerah milik Belanda. Sementara itu, pimpinan perusahaan daerah itu diisi oleh gubernur yang juga anggota militer.

Pada masa Orde Baru, program yang bercorak nasionalistik tergusur seiring dengan upaya membuka kran yang luas kepada investasi asing. Walaupun rezim Orde Baru menegaskan bahwa ideologi yang dipergunakan bukan kapitalisme dan sosialisme, tetapi fakta menunjukkan bahwa penguasaan ekonomi berada di sekelompok elite pengusaha pemilik kapital dan jaringan global di berbagai negara. Inilah mereka, jaringan pengusaha kaya, yang justru semakin meningkat kesejahteraannya, dan bukan negara, apalagi rakyat, sebagai pemilik aset dan kekayaan alam negara. Nasionalisme berakhir di sini, mengingat kedaulatan ekonomi beralih kepada pemodal luar negeri yang berkolaborasi dengan agensi dalam negeri.

Korporasi global semakin menggurita seiring dengan tingginya posisi tawar terhadap negara. Ironisnya, negara menyerahkan sebagian kedaulatan ekonominya terhadap korporasi global yang menguasai sumber daya alam melalui perlindungan Undang-Undang. Kemudian, terdapat penerbitan keputusan pemerintah yang menyangkut pengelolaan kekayaan sumber daya alam terhadap korporasi global dalam durasi waktu tertentu (biasanya cukup panjang). Pascapenerbitan UU Penanaman Modal Asing Tahun 1966, pemerintah memberi kontrak karya selama 30 tahun untuk eksploitasi Papua atau wilayah lain di Indonesia.

Setelah negara terpaksa menyerahkan sebagian kedaulatan ekonominya, pada umumnya negara-negara berkembang memiliki posisi tawar lebih rendah di hadapan korporasi global. Fakta menunjukkan bahwa negara berkembang lebih tunduk terhadap mereka (korporasi global) daripada sanksi yang diberikan oleh lembaga sekelas PBB sekalipun.

Kekuatan jaringan global terwujud dalam korporasi multinasional kenyataannya melampaui kekuatan sebuah negara, termasuk Indonesia. Beberapa korporasi asing yang bisa disebut sangat kaya baik dari perusahaan pertambangan, otomotif, farmasi, maupun bidang lainnya. Selama puluhan tahun negara hanya menerima royalty (jika dalam usaha pertambangan) yang sangat kecil (hanya $1 \%$, kemudian meningkat 3,5\% untuk emas, $4 \%$ tembaga, dan 3,25\% perak), sedangkan pajak minimal dalam bidang otomotif. 


\section{Nasionalisasi Perusahaan Kereta Api: Upaya Menuju Perusahaan Nasional}

Genealogi perusahaan kereta api di Indonesia dimulai akhir abad ke-19, tatkala produk tropis Hindia Belanda menjadi primadona bagi negara induk di Belanda. Diawali pemberian konsesi dari pemerintah Hindia Belanda kepada NISM (Nederlands Indisch Spoorweg Maatschappij), menyusul kemudian berdiri perusahaan kereta api negara (Staatspoorweg Maatschappij), serta berbagai perusahaan kereta api swasta lain hingga semuanya berjumlah 11 perusahaan yang berkompetisi di Sumatera, Jawa, dan Madura. Setelah Belanda menyerah kepada Jepang, riwayat kereta api memasuki episode berbeda. Selama tiga setengah tahun masa pendudukan, Jepang melakukan kebijakan yang merugikan. Juga terjadi kerusakan terhadap infrastruktur kereta api sebagai dampak revolusi fisik, mengingat kaum republik tidak mau Belanda datang lagi. Kondisi rusaknya infrastruktur menimbulkan kerugian terhadap perusahaan. Jepang mencabut beberapa jalur kereta api di kawasan tertentu, untuk dipasang di tanah koloninya di kawasan Asia Tenggara. Salah satu jalur yang dibongkar ialah antara SoloYogyakarta sepanjang $60 \mathrm{~km}$.

Pada 1 Januari 1946 pemerintah Belanda menggabungkan semua perusahaan kereta api menjadi Vereenigde Spoorweg Bedrijven (VS) atau perusahaan kereta api gabungan yang dipimpin oleh Direktur Departemen Perhubungan dan Pengairan. Agar koordinasi antara berbagai perusahaan di atas semakin mudah, struktur jalur yang ada sebelum pada 1942 tidak lagi diberlakukan. Sebagai perusahaan pemerintah, SS diizinkan memasuki kawasan jalur VS untuk kepentingan politik dan militer. Sementara pemerintah menjamin pembukaan jalur-jalur konsesi swasta. Beberapa jalur misalnya Semarang Ambarawa yang sebelumnya dimiliki oleh NISM, selanjutnya bisa dipergunakan oleh SS. Pada 3 Nopember 1947 jalur SemarangDemak, Kedungjati, dan Gubug dibuka kembali untuk lalu lintas umum baik dilewati oleh SS maupun NISM.

Program di atas berlanjut pada Januari 1948 ketika pemerintah Belanda membuat peraturan baru untuk SS yang berlaku sejak 3 Februari 1948. Di antara peraturan tersebut ialah jadwal perjalanan beberapa kota, termasuk Semarang dan Ambarawa yang akan ditempuh dalam waktu tiga setengah jam. Kereta api harus dijamin tersedia untuk jalur transportasi ini seperti transportasi lain antara Semarang dan Gubug serta Semarang dan Kedungjati yang bisa ditempuh dalam waktu 2-3 jam (De Locomotief, 29 Januari 1984).

Di tengah upaya membangun infrastruktur jalur kereta api, kabar mengenai nasionalisasi mulai terdengar. Berbagai perusahaan swasta kereta api mulai resah menjelang akhir 1947. Dengan demikian, berbagai perusahaan tersebut mulai mencatat aset-aset yang dimilikinya. Ketua Direksi NV NISM akan mengunjungi Jawa guna memastikan kebijakan kepada pemerintah Indonesia. Menteri Perhubungan Belanda bersama NV NISM telah membentuk komisi penasehat untuk mempelajari permasalahan menyangkut nasionalisasi perusahaan swasta kereta api. Komisi penasihat ini akan menetapkan nilai ganti rugi berdasarkan jalur, bangunan, serta semua aset yang memiliki investasi tinggi. Bahkan beberapa aset dan jalur ada yang masih berfungsi dengan baik. Nilai investasi akan menyusut f397.000. Kerugian yang tercatat dari 1942 hingga 1949 mencapai f31.731.000 (De Locomotief, 22 November 1947).

Aspek penting dari kemunculan berita nasionalisasi ialah kesadaran di kalangan politisi Belanda mengenai pentingnya sarana dan prasarana transportasi kereta api dalam proyek politik rekolonisasi mereka. Letnan Gubernur Jenderal pada 14 Februari 1948 membuat peraturan mengenai penetapan sementara ganti rugi kereta api di Hindia Belanda. Peraturan ini dibuat guna mendapatkan persetujuan dari pemegang saham. Beberapa perusahaan kereta api swasta melakukan rapat bersama pada 24 Maret 1948, yang dihadiri oleh beberapa perusahaan swasta seperti 
Direksi Perusahaan Semarang Joana Stoomtram Mij, Oost Java Stoomstram Mij, Serajoedal Stoomstram Mij dan Semarang Cirebon Mij. Hasil keputusan rapat tersebut ialah pengeluaran selama kepemilikan yang menyangkut perbaikan, perluasan, dan perlengkapan perusahaan menjadi tanggungan perusahaan terkait. Dalam pemahaman bahwa kesepakatan itu diatur lebih lanjut sampai jumlah beberapa perusahaan itu akan dibebani, dalam kasus pengeluaran itu seluruhnya atau sebagian yang tidak dapat ditanggung oleh perusahaan ini.

Terdapat bukti yang menunjukkan bahwa karena tidak ada dana, kerusakan infrastruktur akibat perang pada jalur-jalur di pedalaman tidak dapat diperbaiki hingga 1948. Kondisi ini tidak hanya menghambat pemulihan transportasi yang berdampak pada kemacetan ekonomi, tetapi juga menimbulkan kerawanan karena menunda beberapa pengangkutan penting yaitu pengungsi yang memerlukan penanganan segera. Hal ini terjadi pada pengungsi Tionghoa di Jawa Tengah yang tidak bisa diangkut oleh Staatspoor karena jalur antara Padas dan Getasan mengalami kerusakan (De Locomotief, 27 Maret 1948).

Dengan berbagai persyaratan bahwa perusahaan menolak setiap tagihan yang diberikan oleh negara maka dibuatlah ukuran ganti rugi yang dibuat atas kesepakatan dari sebelas perusahaan swasta, seperti yang tertera dalam Tabel 1.

\begin{tabular}{lrrrr}
\multirow{2}{*}{ Tabel 1. Rumusan Ukuran Ganti Rugi Perusahaan (dalam Gulden) } \\
\hline Nama Perusahaan & \multicolumn{4}{c}{ Tahun } \\
\cline { 2 - 5 } & $\mathbf{1 9 4 6}$ & $\mathbf{1 9 4 7}$ & $\mathbf{1 9 4 8}$ \\
\cline { 4 - 5 } & & 47.375 & 47.375 & Minimal \\
\hline NV. Kediri & 18.950 & Maksimal \\
NV. Madoera & 52.050 & 130.125 & 130.125 & 208.200 \\
NV. Malang & 38.300 & 95.750 & 95.750 & 153.200 \\
NV. Mojokerto & 13.950 & 34.875 & 34.875 & 55.800 \\
NV. NISM & 777.825 & 1.944 .562 & 1.944 .562 & 3.111 .300 \\
NV. Oost Java & 70.750 & 176.875 & 176.875 & 283.000 \\
NV. Pasuruan & 6.975 & 17.438 & 17.438 & 27.900 \\
NV. Probolinggo & 11.680 & 29.625 & 29.625 & 47.400 \\
NV. SJS & 107.725 & 268.187 & 268.187 & 429.100 \\
NV. SCS & 265.950 & 664.875 & 664.875 & 1.063 .800 \\
NV. SDS & 46.125 & 115.313 & 115.313 & 184.500
\end{tabular}

Sumber: Ringkasan Daftar Keputusan Letnan Gubernur Jenderal Hindia Belanda No.12 Tahun 1948 , Koleksi National Archief van Nederlands.

Mengenai besaran jumlah uang selama 1948 akan dibuat kesepakatan lebih lanjut, ganti rugi selama 1946 dan 1947 bisa ditagihkan pada 29 Februari 1948, sementara selama tahun itu pada 30 Juni separuh dari jumlah minimal bisa dibayarkan dan sisanya pada akhir Desember 1948 (Nieuwe Courant, 17 Maret 1948). Proses ganti-rugi di Belanda juga akan dibayarkan dalam Rekening Koran Belanda, sejauh aturan-aturan yang berlaku mengizinkannya. Kemungkinan berakhirnya eksploitasi negara sebelum 1948 terbuka dalam keputusan terkait, sementara ganti rugi bagi pengguna setelah tahun itu tetap menjadi agenda pembahasan lebih lanjut.

Nasionalisasi sebagai sebuah upaya memiliki makna berbeda dalam implementasinya. Pertama, overneming yang berarti pengambilalihan semua hak dan tanggung jawab perusahaan, mulai dari pegawai, aset, maupun utang. Dalam skema ini tidak ada skema ganti rugi. Perusahaan yang terkena dampak peraturan ini adalah Staatspoor (SS). Landasan hukumnya adalah KMB pada Desember 1949. Kedua, bezitneming yang berarti perusahaan yang sudah habis masa konsesinya dan tidak diperpanjang. Semua aset atau kekayaan perusahaan dibeli oleh negara, 
kecuali utang-utang yang tetap ditanggung oleh perusahaan. Perusahaan yang terkena aturan pemutusan konsesi 1954 ini ialah Semarang Cirebon Stroomtaam Maatschappij yang beroperasi di Cirebon. Ketiga, naasting, yaitu pengambilalihan secara sepihak yang dilakukan oleh pemerintah berdaulat terhadap perusahaan asing yang beroperasi di negara tertentu. Model ini disebut sebagai schade loostelling atau ganti kerugian. Para pengusaha asing yang tidak bersedia dengan model ini menggugat ke pengadilan internasional di Jerman pada 1960, dengan harapan pemerintah Indonesia untuk menggunakan model pembelian seperti model nomor dua. Permohonan para pengusaha asing ini ditolak oleh mahkamah internasional dengan alasan bahwa negara yang sudah berdaulat berhak melakukan nasionalisasi. Beberapa pengusaha Belanda seperti J.L. Geesink dari pabrik Karung Delanggu, G.H.A. Alferink dari S.E.M. Solo, K.J. Moet dari Javasche Bank di Solo, dan G.B.T. Luitink dari Pabrik Modjo di Sragen, serta NISM.

Terdapat surat Menteri Perhubungan Juanda tertanggal 26 Februari 1953 yang menyatakan beberapa persoalan mendasar mengenai nasionalisasi perusahaan kereta api swasta di Jawa dan Madura. Latar belakang pembuatan surat tersebut antara lain, pertama, berpijak dengan Surat Keputusan Menteri Perhubungan, Tenaga Kerja dan Pekerjaan Umum Nomor 3079/Ment tanggal 19 Agustus 1950. Dalam keputusan Menteri Perhubungan tersebut terdapat keputusan pembentukan panitia yang bertugas memberi laporan secara seksama tentang jumlah uang yang akan dipergunakan untuk pengeluaran perusahaan kereta api swasta, dan syarat-syarat pembayaran retribusi.

Landasan hukum pengambilalihan perusahaan kereta api swasta tersebut ialah ordonnantie medewerking bedrijven, sedangkan landasan hukum antara perusahaan swasta dan pemerintah berdasar pada perjanjian overeenkomst yang mengandung ketentuan tentang besarnya jumlah uang penggantian yang setiap tahun harus dibayarkan oleh pemerintah terhadap perusahaan-perusahaan tersebut (Lihat Surat Menteri Perhubungan RI tanggal 26 Februari 1953).

Salah satu perusahaan kereta api swasta yang tidak terima dengan nasionalisasi ialah NISM. Namun demikian, setelah adanya kebijakan pembatalan perjanjian KMB dan pengesahan UU Nasionalisasi Perusahaan Milik Belanda pada 1958, maka semua perusahaan kereta api swasta Belanda di Jawa dan Madura telah dinasionalisasi. Pemerintah mengeluarkan Peraturan Pemerintah Nomor 40 Tahun 1959 tertanggal 25 Juli 1959. Terdapat sepuluh perusahaan kereta api swasta yang dinasionalisasi. Peraturan Pemerintah ini berlaku surut dan dinyatakan mulai berlaku pada 3 Desember 1957. Sementara itu, pemerintah juga mengeluarkan PP Nomor 41 Tahun 1959 tentang Nasionalisasi Perusahaan Kereta api dan Telpon milik Belanda. Latar belakang pengambilalihan ini adalah karena kereta api adalah moda pengangkutan barang produksi dan manusia yang diperlukan banyak orang. Karena itulah, pemerintah melihat urgensi kepentingan publik untuk melakukan nasionalisasi kepada perusahaan kereta api dan telepon.

Berdasar pasal 4 PP No. 2 Tahun 1959 tentang Pokok-Pokok Nasionalisasi Perusahaan Belanda, terdapat pembentukan Badan Penampungan Perusahaan, Badan Nasionalisasi Perusahaan Belanda dan Badan Penetapan Kerugian. Panitia ini terdiri atas Wakil Kementerian Kehakiman sebagai Anggota merangkap Ketua, Wakil Kementerian Keuangan sebagai anggota merangkap Wakil Ketua, dan Wakil Kementerian Keuangan sebagai anggota. Sementara itu, PP No. 22 Tahun 1963 membuat status Djawatan Kereta Api menjadi Perusahaan Negara Kereta Api (PNKA) dengan mengangkat Ir. R. Aboeprajitno sebagai Direktur Jenderal PNKA. Kemudian perusahaan ini berubah lagi menjadi Perusahaan Jawatan Kereta Api (PJKA) pada 1971 melalui Keppres No. 44 dan No. 45 Tahun 1974. PJKA menjadi unit organisasi dalam lingkungan Departemen Perhubungan dengan kedudukan, fungsi, tugas, serta susunan organisasi yang diatur tersendiri. 


\section{Simpulan}

Situasi dan kondisi sosial politik dalam dan luar negeri pascaproklamasi 1945 hingga pertengahan 1950-an turut berperan dalam mendorong lahirnya kebijakan nasionalisasi perusahaan Belanda yang berwatak sosialis. Situasi tersebut menjadi latar belakang adanya keinginan lahirnya nasionalisasi atau pengambilalihan milik asing yang sebenarnya milik bangsa Indonesia. Nasionalisasi ekonomi merupakan bagian dari kebijakan politik ekonomi yang gencar dilakukan seiring keinginan mengembalikan peran pribumi dalam pembangunan ekonomi pada era 1950-an. Berbagai upaya dilakukan pemerintah seperti Program Benteng namun tidak memberikan hasil seperti yang diharapkan. Program yang diharapkan mengangkat peran pengusaha pribumi agar mampu bersaing dengan pengusaha Cina dan Belanda, ternyata tidak berhasil dan justru menimbulkan persoalan baru.

Kenyataan menunjukkan bahwa nasionalisasi perusahaan kereta api mengalami hambatan dari aspek politik sehingga dilakukan proses negosiasi politik yang dihadapi oleh pemerintah, terutama dari pihak perusahaan kereta api swasta yang semula tidak menerima kebijakan nasionalisasi yang kemudian berujung pada kesepakatan pembayaran ganti rugi yang dicicil oleh pemerintah Orde Baru selama 30 tahun mulai 1973 hingga 2003.

\section{Referensi}

Achmad, S. (1963) The dynamics of the nationalization of Dutch-owned enterprises in Indonesia: A political, legal, economic development and administrative analysis. Indiana University.

Chalmers, I. (1996). Konglomerasi: Negara dan modal dalam industri otomotif Indonesia. Jakarta: Gramedia Pustaka Utama.

Feith, H. dan Castle, L. (Ed.) (1990). Pemikiran politik Indonesia. Jakarta: LP3ES.

Glassburner, B. (2007). The economic policy making in Indonesia, 1950-1957. Dalam B. Glassburner (Ed.), The economy of Indonesia: Selected readings. Equinox Publishing. Jakarta-Kuala Lumpur.

Kanumoyoso, B. (2001). Nasionalisasi perusahaan-perusahaan Belanda. Jakarta: Sinar Harapan.

Kementerian BUMN (2014). Sejarah nasionalisasi aset-aset BUMN: Dari perusahaan kolonial menuju perusahaan nasional. Jakarta: Kementerian BUMNI.

Mackie, J.A.C. (2007). The Indonesian economy, 1950-1963. Dalam B. Glassburner (ed). The economy of Indonesia: Selected readings. Equinox Publishing. JakartaKuala Lumpur.

Muhaimin, Y. A. (1991). Bisnis dan politik, kebijaksanaan ekonomi Indonesia 1950-1980. Jakarta: LP3ES.

Nederlands Indonesiche Spoorweg Maatschappij. (22 November 1947). De Locomotief, lembar ke-2.

Nieuwe dienstregeling der spoorwegen. (29 Januari 19498). De Locomotief.

Pelzer, K. J. (2007). Agricultural foundation. Dalam Bruce Glassburner (ed). The economy of Indonesia: Selected readings. Equinox Publishing. Jakarta-Kuala Lumpur. 2007.

Rahmat, M. \& Yustika, A. E. (2017). Dari nasionalisasi menuju liberalisasi ekonomi. Malang: Empat Dua.

Ricklef, M.C. (2008). Sejarah Indonesia modern 1200-2004, Jakarta: Serambi Press.

Sutter, J. (1959). Indonesianisasi: Politics in a changing economy, 1940-1955. Cornel University Press, Ithaca.

Thee Kian Wie (2010). Understanding Indonesia: The role of economic nationalism. Journal of Indonesian Sciences and Humanities. Vol. III, pp. 55-79.

Tijdelinkenaasting spoor an tramwegen. (17 Maret 1948). Nieuwe Courant, lembar ke-2. 